\title{
Long-term cereal price changes: how important is the speculative element ${ }^{1}$
}

\author{
M. Bruna Zolin \\ Università Ca' Foscari di Veneria \\ Bernadette Andreosso-O'Callaghan \\ University of Limerick.
}

First Draft: 20.07.2010

\begin{abstract}
The objective of this article is to provide an analysis of the relationship existing between cereal prices and several variables such as population, income, exports, the exchange rate, and speculation, by using a linear regression analysis. Specific emphasis is placed on the speculative dimension. The methodology used helps us explore the forms of relationships between the different variables, and, more specifically, it gives an insight into the extent of speculation during the recent critical time period. Our results show that speculation (defined by the long position of traders) has played a crucial role during the period June 2001 December 2009. According to our analysis, speculation it is the most relevant independent variable that affects cereal prices. Exports, in some ways connected to the former variable, occupy second place, in term of significance. However, their impact on cereal prices is less relevant than that of biofuel production. Population growth does not have impact in a positive way on cereal prices; it acts in the opposite direction due to the change in diets, implying that population increases would tend to affect primarily other agricultural markets. Excessive volatility in food prices, as that observed in the last years is a dramatic question. From a demand point of view, consumers in developing countries and vulnerable income groups in other countries (farmers) have to be protected. More than one policy on both international markets and domestic markets have to be introduced so as to lessen food/cereal lower price volatility.
\end{abstract}

Keywords cereal prices, future markets and speculation, renewable energy, agricultural demand and supply.

JEL Codes Q11, Q18, Q17, O13, 052, 053, F43

Address for correspondence: Maria Bruna Zolin Department of Economics Ca' Foscari University of Venice Cannaregio 873, Fondamenta S.Giobbe 30121 Venezia - Italy

\footnotetext{
1 The authors would like to acknowledge the precious help provided by Elisa Guerra and Andrea Lucchetta in the sourcing and elaboration of statistical data and to Domenico Sartore for his valuable comments on an earlier draft. The Working Paper Series Department of Economics is availble only on line $\quad$ Ca' Foscari University of Venice (www.dse.unive.it/pubblicazioni) Cannaregio 873, Fondamenta San Giobbe For editorial correspondence, please contact: 30121 Venice Italy wp.dse@unive.it $\quad$ Fax: ++390412349210
} 
Phone: (++39) 0412349132

Fax: (++39) 0412349176

e-mail: zolin@unive.it

This Working Paper is published under the auspices of the Department of Economics of the Ca' Foscari University of Venice. Opinions expressed herein are those of the authors and not those of the Department. The Working Paper series is designed to divulge preliminary or incomplete work, circulated to favour discussion and comments. Citation of this paper should consider its provisional character. 


\section{Introduction}

Whereas during the period spanning over the years 1974-2005, food prices on world markets fell by three-quarters in real terms, the sudden increase of food prices since 2005 seems to have started a new era of 'agflation'. Although the changing food patterns in large emerging economies such as China and India and the increased land requirements for growing non-food crops aimed at the transport sector in developed economies explain part of this increase, the speculation in physical commodities market (such as corn, coffee, cocoa and wheat) may also have a role to play. The diminishing arbitrage prospects by investors in the currency markets, combined with the credit crunch and the housing crash, have caused a flight to food and energy commodities.

According to FAO sources (FAO, 2009), the food price index of internationally traded basic food commodities (base 100 in 2002-04) fell a full 35 per cent between the peak in June 2008, to the end of April 2009. In May 2009, the index was 152.70 percent higher than the 2000 level. Because of the interaction between demand and supply, agricultural prices tend to be volatile and the activity of speculators can amplify these fluctuations.

Agricultural products consist usually of basic food, and they represent the main component of rural incomes as well as the diet of poor segments of populations in developing countries. This means that high food prices hit primarily poor consumers, and that low agricultural prices hit poor farmers. The objective of this article is therefore to provide an analysis of the relationship existing between cereal prices and several variables such as population, income, exports, the exchange rate, and speculation, by using a linear regression analysis (Section 4). Specific emphasis will be placed on the speculative (or arbitrage) dimension in cereals markets (Section 3). The time period covers the years June 2001 - December 2009 and the analysis encompasses four major commodities, namely corn, rice, wheat and barley. The methodology used helps us explore the forms of relationships between the different variables, and, more specifically, it gives an insight into the extent of speculation during this critical time period. The analysis will conclude with policy recommendations in the area of agricultural and commodity markets (Section 5). Beforehand, a few insights into the main demand and supply explanatory factors of agricultural commodity (cereals) prices will be scrutinized (Section 2).

\section{Demand and supply drivers}

The factors that affect the pricing of agricultural commodities (particularly cereals) are complex; they are widely debated and analysed. Many authors 
conclude that the most important factor of the rapid recent rise in food prices is the large increase in biofuel production, mainly in the industrialized countries (Mitchell, 2008; Kutas et al, 2007; IFRI, 2008; Muller, 2008). Others identify speculation as a source of increasing agricultural commodity prices in 2007-2008 (Robles et al 2009; Walp, 2009; Timmer, 2009; Pace et al, 2008). Although the relative importance of the different explanatory variables vary across studies, these analyses tend to agree with the broad conclusion that behind the rapid increase (and then decrease) in food prices, there are several factors at play.

Graph 1 shows the recent price hike (2007-2008) in the case of the four crops under review, namely barley, corn, rice and wheat. One should note that a certain trade-off exists between the different crops, implying that an increased demand for one specific cereal (corn, as example) may have an indirect impact on the price of other crops such as rice. When food prices increased in 2007-2008, the role of speculation in these markets was almost entirely ignored, while the production of biofuels was considered as the main responsible factor for these sharp increases. The decrease in food prices from July 2008 posed a new intriguing question. Neither an increasing demand emanating form emerging countries, nor agro-fuel production could totally be responsible for rising prices, and then for their aftermath decrease.

The reason for the interest in cereal price volatility is that cereals (grains or cereal grains) provide more food energy worldwide than any other type of crop; they are therefore staple food. In some developing countries, cereals in the form of corn (wheat or rice), constitute a large proportion of the average household's daily subsistence. In developed countries, they are still important, although their level of per capita consumption is substantially lower than in developing countries. 


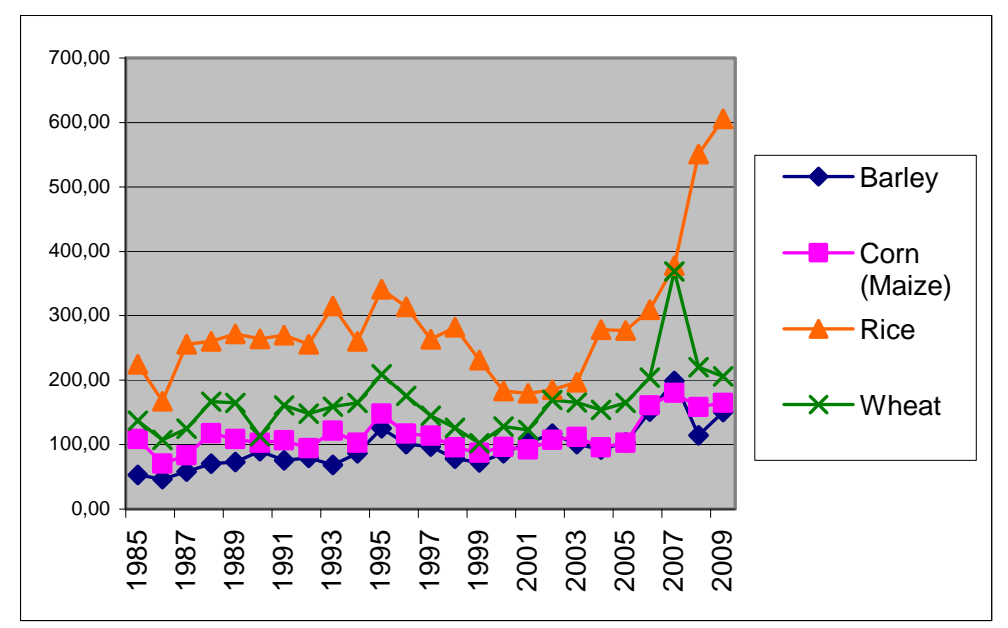

Source: IMF wnw.imf.org

The factors affecting agricultural commodity prices are both supply and demand driven factors. Among the supply factors (partially explored in this analysis because of their statistical insignificance in our regression analysis), are input costs and land utilization. Productivity, defined as yield per ha and made possible by research and development efforts, as well as stocks are the only supply-side factors included in our study. The reductions of food stocks are particularly relevant in the context of the European Union. From a demand-side perspective, the possible explanatory variables are: population, GDP, demand for cereals for energy purposes, exports, exchange rates, and futures markets (as a proxy for the speculative element) are the retained in the analysis.

Population is normally included as one variable that impacts on world food demand. As once espoused by Robert Malthus, a rise in the population is necessarily limited by the means of its subsistence, implying that a rising population must go hand in hand with a proportional increase in the supply of agricultural products. The rapid income growth in some emerging countries such as China and India in the years preceding agricultural price increases have led to a fall in the growth rate of the population of these countries, whereas their changing diet patterns, as mentioned below, have exerted some strain on the demand for cereals. Despite these trends, productivity rises explain why population growth has been playing only but a small role in the rise of food demand since WWII.

A second important explanatory variable relates to income. GDP and per capita GDP changes usually have a greater impact on food demand in developing countries (and on low-income group households therein) because food consumption forms a larger part of households' budgets, 
compared with many industrialised countries where food expenditure represents in general a smaller proportion of the average household's budget, and where it is less responsive to changes in both incomes and prices (Engel's law). The rise in GDP per capita, notably in the emerging countries during the years preceding the recent price hikes, has led to shifting diet patterns away from cereals and towards meat; this, in turn, puts an extra pressure on the demand for cereals (specifically wheat and corn) as an input for the increased production of meat, upward pressures that are depicted in Graph 2. Again, it seems a priori that it is more the shifting consumer patterns rather than the increase in population per se that explain production increases over the period under review (2001-09).

\section{Graph 2 - Cereal production trends, 1,000 tons (1985-2009)}

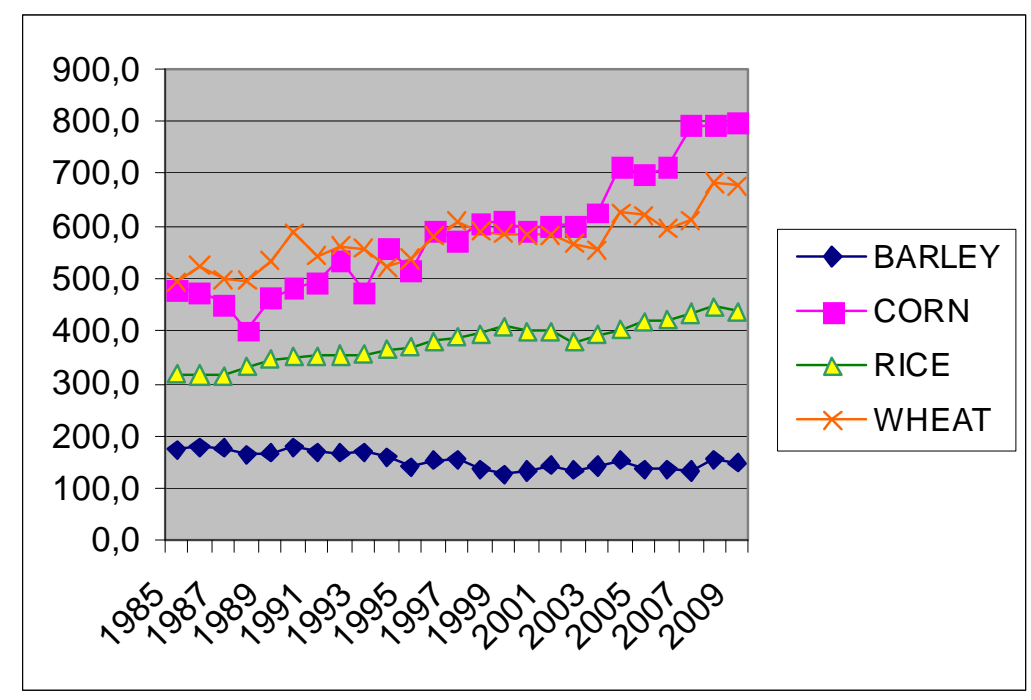

Source: Authors' elaboration based on USD A data.

Corn is the third largest planted crop after wheat and rice. Even if corn has been considered as a food crop for quiet some time, it has evolved gradually as feed grain affecting the trade volume in response to rising demand from the fast growing livestock sector. Beside, corn has become one of the most popular raw materials of the expanding ethanol industry during the last years of our analysis. Over the 1985-2009 period, global corn production has increased by 66 per cent (from 479 thousands million tons in 1985 to 797.8 thousands in 2009), whereas its consumption has risen by 93 per cent (from 417.7 thousands tons in 1985 to 807.4 thousands in 2009). The harvested area increased by 18 per cent only, but average corn yields moved from 3.66 to 5.14 tons/ha respectively in 1985 and 2009 (40 per cent). This is the direct result of the biotechnology revolution (with 
the emergence of genetically modified corn seed $\mathrm{Bt})^{2}$ that has widely penetrated the area of corn production. Corn is therefore more closely linked to crude oil because it is a raw material for ethanol production, and it can therefore increasingly be seen as a substitute component of crude oil. Corn for food therefore increasingly competes with corn produced for energy purposes.

Wheat is the most important cereal in international trade because of its easiness of transportation and processing processes. In the list of staple foods, it ranks second after rice. About two thirds of its production is for human consumption and approximately one sixth is used for livestock feed. World wheat production was equal to 363 million tons in 1985 and in 2009 it reached 410.5 million tons. During the same period, productivity increased without reaching the high levels observed during the so called “green revolution" period.

Rice $^{3}$ is the third most produced cereal in the world. Rice production in 1985 was around 318 thousands tons and by the end of 2009 it had reached 436.3 thousands tons. The harvested area increased from 144.7 thousands to 152.5 thousands ha from 1985 to 2009 and productivity rose from 3.23 to 4.27 tons/ha in 1985 and 2009 respectively. At the time of writing, no large scale production of genetically modified rice is taking place. Consumption trends are similar to those of production (306.8 in thousands tons 1985 versus 434 in 2009). International trade is very low, due to a high level of domestic consumption in producing countries. Rice production is indeed cconcentrated in Western and Eastern Asia which account for more than 90 per cent of the total world production. The role of speculation in the rice market has usually not been included in analyses because of the marginal incidence of rice futures markets and trade (Timmer, 2009).

Barley is more adaptable than other cereals, in that it tolerates many diverse environments. It can be grown on soils or at altitudes unsuitable for wheat. Furthermore, due to its salt and drought tolerance it can be grown near desert areas. Barley is a staple grain for many animal feeds in many countries, but its importance for malt beverages is a cultural factor that contributes to its significance in certain parts of the world. At the world level, production, total consumption and harvested areas have shown a decrease over the 1985-2009 period. In the period under analysis, the harvested area fell from 80 thousands ha in 1985 to 55.2 thousands ha in 2009, total consumption from 168.3 thousands tons to 146.2 thousands

\footnotetext{
2 International trade in genetically modified corn is complicated by trade regulations within the WTO, namely, the application of Sanitary and Phyto-Sanitary Measures and Technical Barriers to Trade (TBTs).

${ }^{3}$ In our analysis we consider milled rice.
} 
tons, and production from 176.6 thousand tons to 148.9 thousand tons. On the other hand, productivity increased from 2.17 to 2.7 tons/ha.

\section{Graph 3 - Productivity trends, tons/ha (1985-2009)}

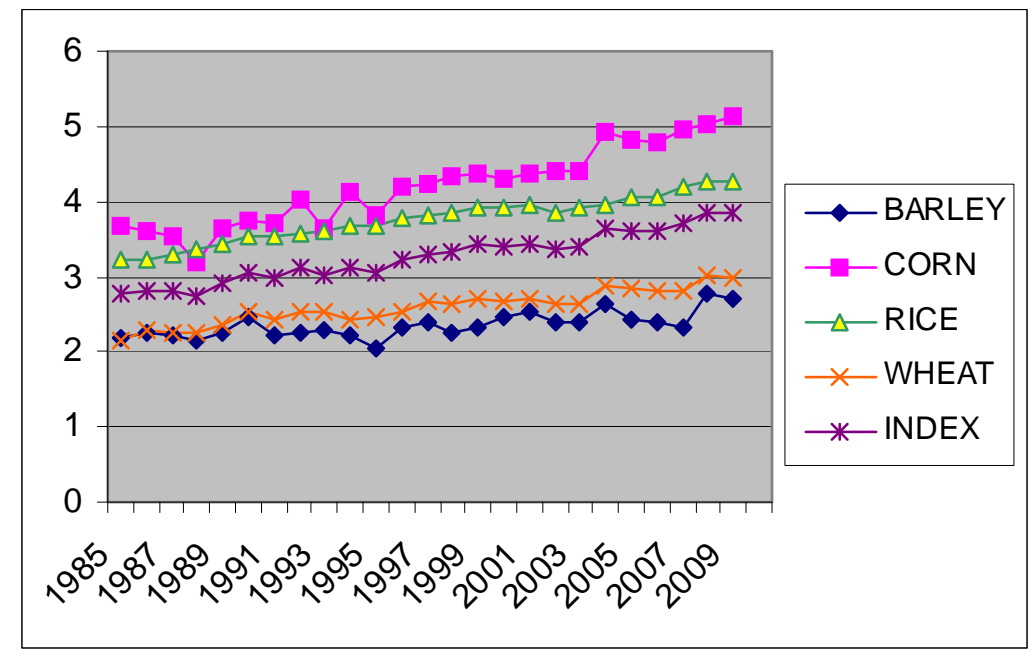

Source: Authors' elaboration based on USDA data.

In 2008, supply responses to high prices and lower input prices (mainly energy) is evident in the case of corn and wheat (Graph 2) where the production increased, while it decreased for rice. In the future, the growth of cereal production can be predicted outside the industrialised nations, where productive factors are not fully utilised. In fact, there is a large amount of uncultivated or underutilized land, mainly in developing countries. The relatively large share of rice in total cereal production comes from increased agricultural productivity (Graph 3), but increased production requires higher productive costs per unit. The yield of grain crops has been increasing since the advent of the agricultural revolution and now agricultural productivity growth is slowing. 


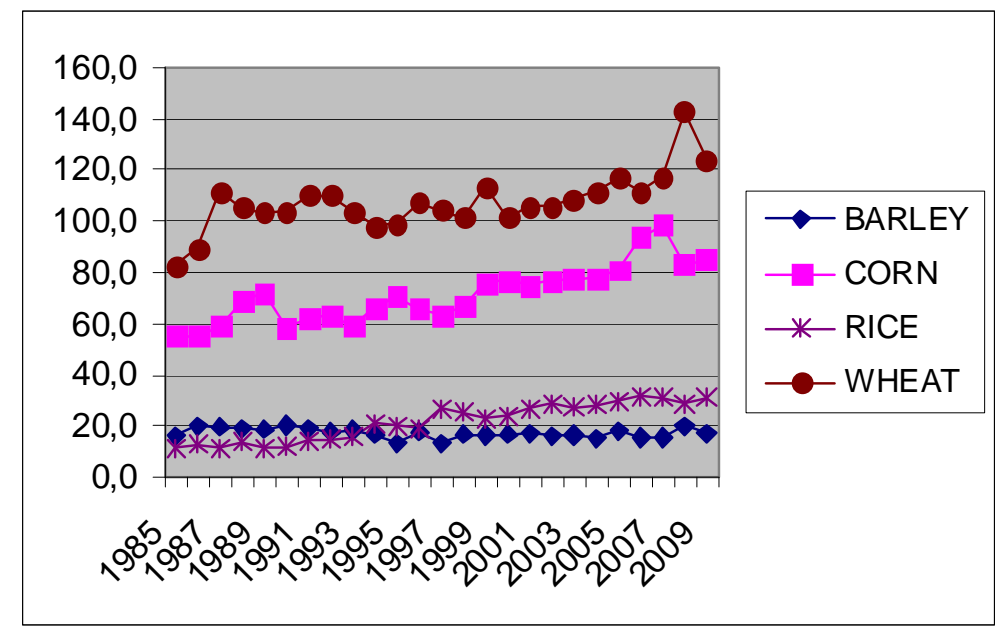

Source: Authors' elaboration based on USDA data.

With regard to world exports, it appears that trade volumes in corn and wheat are sensitive to a number of economic conditions, such as the global recession of 2008-2009.

The level of ending stocks is an important signal for cereal suppliers and therefore these stocks affect prices. These stocks play the role of buffer stock schemes and, as a consequence, they look as an attempt to use cereals for the aim of stabilising prices in the world economy. They are a reserve against short term shortages and/or instruments to control excessive fluctuations in the commodity prices. By analyzing graphs 1 and 5 together, we can observe a negative correlation between stocks (Graph 5) and world prices (Graph 1): low stocks increase the perception of a reduction in supply; great fluctuations and a general dramatic decrease (except in barley) can be observed mainly over the period 2006-2008. These stocks have a positive role in stabilizing prices, with stocks increasing when prices are lower (withdrawal of supply by intervention agencies) and falling when prices are higher (flooding markets with additional supply). With regard to operators, it could be interesting to distinguish between institutional and private operators. Private operators are motivated by self-economic interest, and public operators by public goals. In the analysed period, both private and public types of interventions were at play, and the exact contribution of either type of operators is beyond the scope of the present analysis. 


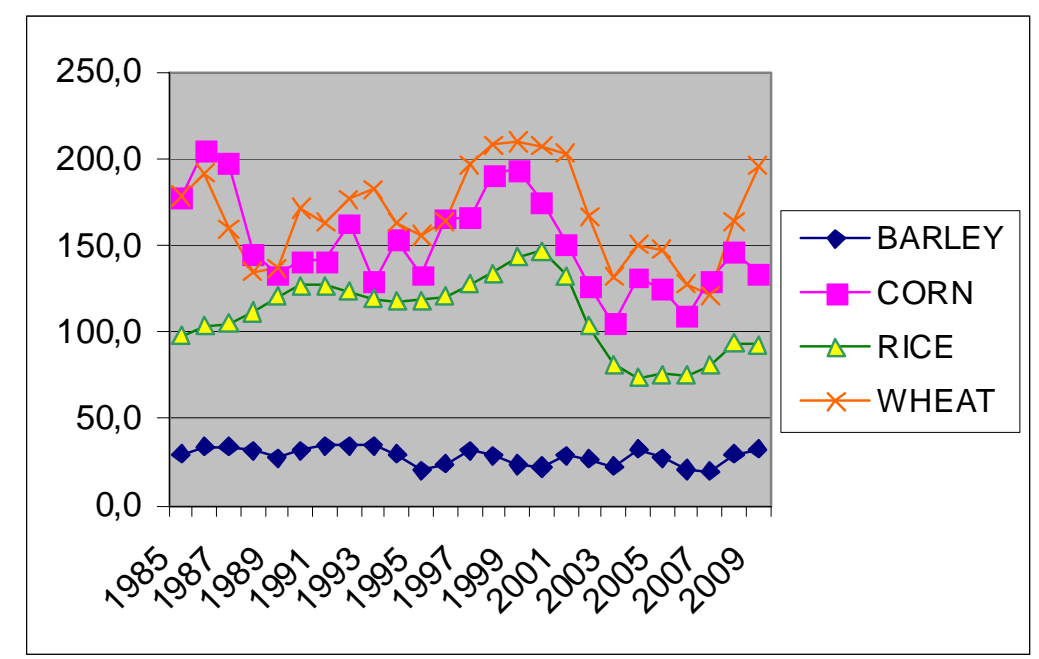

Source: USDA.

\section{Speculation}

Speculation is strictly linked to ending stocks. Speculation can be defined as the assumption of the risk of loss in return for the uncertain possibility of a reward (Robles et al, 2009). On the futures market, speculators may act in the long ${ }^{4}$ and short $^{5}$ side of any single such transaction, but in the aggregate, their commitments must offset any net imbalance in the long and short hedgers' position. Speculation can either reduce price fluctuations or aggravate them; it can be stabilising or destabilising. Excessive speculation in the commodities futures markets can affect spot prices above levels due to standard supply and/or demand determinants through futures prices. In the context of food markets, price volatility can be highly disruptive in terms of economic policy and destabilising from a socio-economic standpoint.

${ }^{4} \mathrm{~A}$ 'long position' consists in the buying of a commodity with the expectation that the asset will rise in value.

${ }^{5} \mathrm{~A}$ short position involves the sale of a borrowed commodity with the expectation that the asset will fall in value 


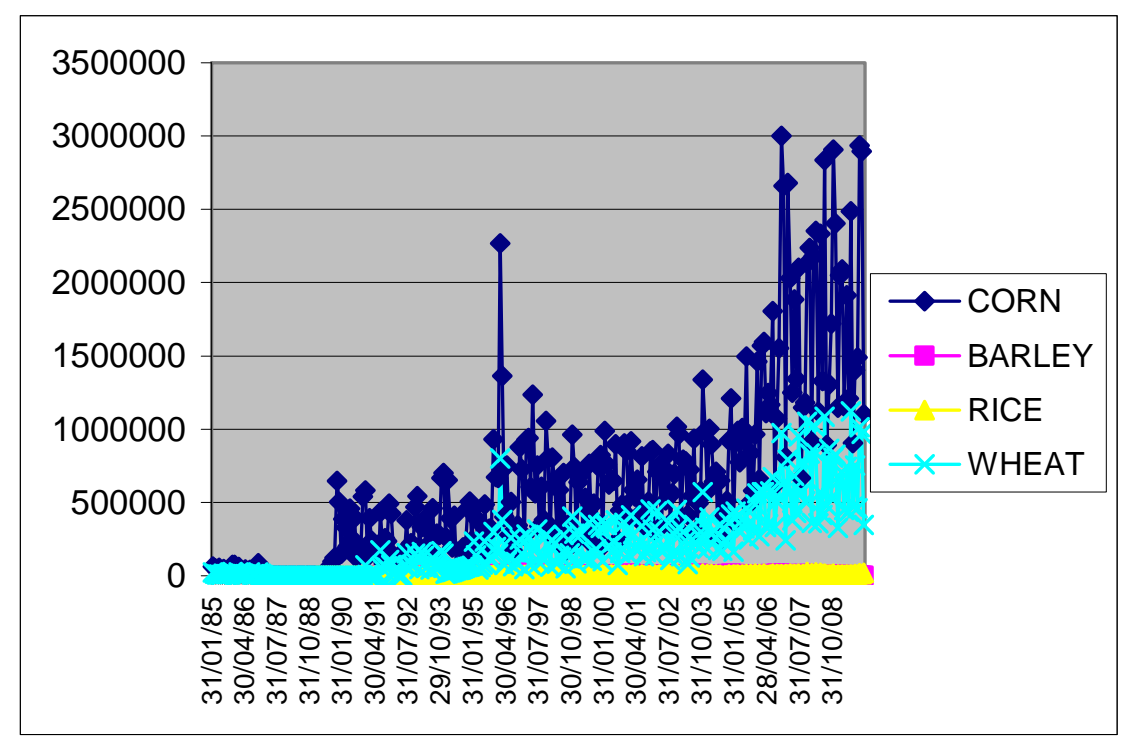

Source: Bloomberg.

A market with a high number of contracts is attractive from a trading stand-point. As shown in graph 6, the main cereals markets affected by futures contracts are corn and wheat, whereas rice and barley markets are characterised by low and stable movements. As was discussed above, the former two agricultural commodities are more affected by significant changes in supply and demand than the latter two markets..

Open interests relate to the measurement of those participants in the futures market with outstanding trades. It represents the net value of all open positions in one market or contract. When the open interest increases with a correspondingly quick rise in prices (as in our case), more traders are likely to enter long positions ${ }^{6}$. If the prices keep rising, the traders in long positions will have the ability to hold their position for a greater period of time while those in short position are more likely to be forced out of their position. As depicted in graphs 6 and 7, we can observe a great variability in corn followed by wheat, both in terms of futures and open interests; this variability signals that speculation has a crucial role in these agricultural commodity markets and has potentially an important impact on prices. By contrast, minor variations characterise rice, and it can be argued that a trade-off among corn and/or wheat and rice is potentially under play.

\footnotetext{
${ }^{6}$ That said, for every new buyer of a futures contract, there must be a new seller, but the seller is likely to be looking to hold a position for a few hours or days, hoping to benefit from the ups and downs represented by price movements.
} 


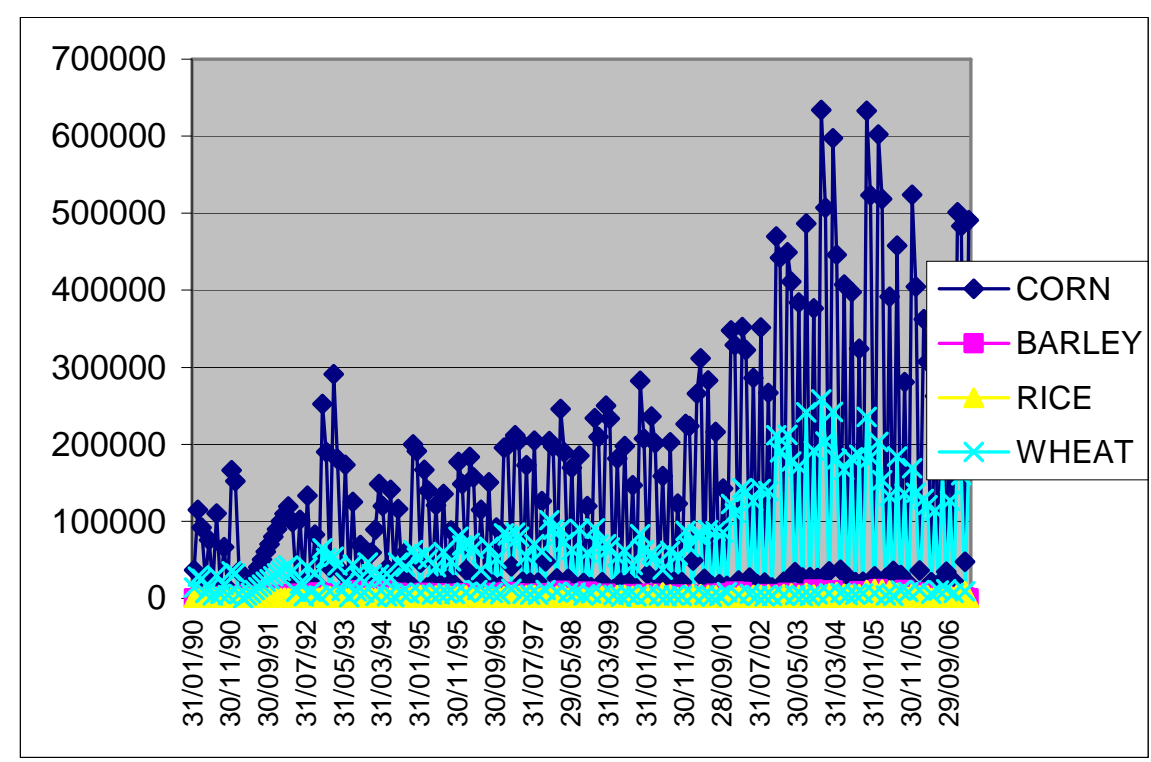

Source Bloomberg

The relative stability of rice in both futures volumes and open interests is partially due to the small quantity of rice traded on the international market and to the strong public policies adopted by some producing and consumer countries as a consequence of soaring prices.

\section{Results - Explanatory factors of cereal price changes}

In our uniequational regression analysis, the dependent variable is the logarithmic of IND_PR (i.e. the spot cereal price index build by Standard\&Poor's "S\&P GSCI Grains Index" is used as a benchmark). The utilised method is Ordinary Least Squares (OLS). Since the increase in demand for cereals may have different implications in the short-run and in the long-run at both the farm and macroeconomic levels (economic and social), it is convenient to distinguish between them. Our analysis will nevertheless focus on the results in the long-run only ${ }^{8}$.

The sample spans over mid-2001 to December 2009, and relies on high frequency data. Although not every data point is available for the entire period of time, E-Views automatically adjusts the sample, considering only the period of time for which all time series are simultaneously available.

7 It includes corn, soybeans, Chicago wheat (soft, red winter wheat) and Kansas Wheat (hard, red winter wheat or red wheat) prices in variable proportions. Note that the utilisation of the logarithmic scale allows to linearise their behaviour and to assess them in elasticity terms.

${ }^{8}$ The long-run equation (Table 1) is not a spurious regression. All the variables that enter in the equation are integrated of order one. Nevertheless, the ADF test on the residuals of this equation refuses the presence of unit roots, so that all the variables in the model are cointegrated, that is, the regression coefficients are meaningful and can be interpreted as long-run coefficients. 
The short run regression utilises the first difference of the variables. For this reason, an observation is missing (the first) and the sample is adjusted without the missing data. A Newey-West HAC Standard Errors \& Covariance (lag truncation $=4$ ) estimator allows to obtain consistent estimates of standard errors with respect the autocorrelation and heteroskedastic effects.

The variables the estimated parameters of which are statistically insignificant have been eliminated from the analysis. This leaves the following variables, by order of significance: long position of traders, exports, dollar-euro exchange rate, ending stocks, population (inverse relationship), biofuel production, productivity (inverse relationship), and futures. The results are given in Table 1 (in logarithmic levels), Table 2 (percentage of increments of the dependent variable LOG(IND_PR) when one explanatory variable is incremented by $1 \%$ ) and Table 3 (percentage of increments of the dependent variable (IND_PR), without the log transformation, if one explanatory variable is incremented by $1 \%$ ).

First of all, the results of the adjusted R-squared show that more than 93 per cent of the variation of cereal prices is explained by the regression analysis and that this model has therefore a rather large explicative power. 
Table 1 - Regression results - long-run analysis (levels)

Dependent Variable: LOG(IND_PR) (Price Index)

Sample: 2001M06 2009M12: observation: 103

Newey-West HAC Standard Error \& Covariance (lag truncation=4)

\begin{tabular}{|c|c|c|c|c|}
\hline & Coefficient & Std. Error & t-Statistic & Prob. \\
\hline $\mathrm{C}$ & 158.1056 & 45.40055 & 3.482460 & 0.0008 \\
\hline LOG(POP) (Population) & -10.38862 & 2.946464 & -3.525793 & 0.0007 \\
\hline $\begin{array}{ll}\text { LOG(BIOC_PROD }) & \text { (Biofuel } \\
\text { production) } & \end{array}$ & 0.530789 & 0.151394 & 3.506000 & 0.0007 \\
\hline $\begin{array}{l}\text { LOG(IND_Y) } \quad \text { (Productivity } \\
\text { Index })\end{array}$ & -2.232498 & 0.835315 & -2.672643 & 0.0089 \\
\hline $\begin{array}{l}\text { LOG(IND_ES) (Index of Ending } \\
\text { Stocks) }\end{array}$ & 0.622805 & 0.142500 & 4.370549 & 0.0000 \\
\hline $\begin{array}{l}\text { LOG(IND_EXP) } \quad \text { (Index of } \\
\text { Exports) }\end{array}$ & 2.786491 & 0.413784 & 6.734175 & 0.0000 \\
\hline LOG(EXRATE) (Exchange Rate) & 1.153424 & 0.201476 & 5.724874 & 0.0000 \\
\hline $\begin{array}{l}\text { LOG(INDEX_FUTVOL/INDEX } \\
\text { _OPINT) (Index of Futures) }\end{array}$ & 0.010637 & 0.004344 & 2.448719 & 0.0162 \\
\hline $\begin{array}{l}\text { LOG(NC_LONG/(NC_LONG+ } \\
\text { C_LONG)) (Long-term position } \\
-2 \text { types of agents, private and } \\
\text { public) }\end{array}$ & 0.516327 & 0.047049 & 10.97415 & 0.0000 \\
\hline
\end{tabular}

\begin{tabular}{|l|l|}
\hline & Coefficient \\
\hline R-squared & 0.943718 \\
\hline Adjusted R-squared & 0.938928 \\
\hline S.E. of regression & 0.081758 \\
\hline Sum squared resid & 0.628327 \\
\hline Log likelihood & 116.4696 \\
\hline F-statistic & 197.0209 \\
\hline Prob (F-statistic) & 0.000000 \\
\hline
\end{tabular}

With regard to the partial correlation, the value is very high in the cases of population and biofuel production (almost equal -1 and 1 respectively), showing a strong correlation between these single explanatory variables and the dependent ones. Medium levels are observed in the index of exports and exchange rate, while lower correlations characterise the index of futures, the index of ending stocks, the long term positions and finally the productivity index.

The percentage variations in logarithmic scale (Table 2) show that a one percent increase in population will decrease cereal prices by 29 percent, 
and that a one percent increase in biofuel production will result in a 0.56 percent increase in price.

Table 2 - Percentage of increments $(\Delta \%)$ of the dependent variable LOG(IND_PR) when one explanatory variable is incremented by $1 \%$

\begin{tabular}{|c|c|c|}
\hline Explanatory Variables & $\Delta \%$ & partial correlation \\
\hline LOG(POP) (Population) & $-29.10 \%$ & -0.950177 \\
\hline LOG(BIOC_PROD)) (Biofuel production) & $0.56 \%$ & 0.969061 \\
\hline LOG(IND_Y)(Productivity Index) & $-0.51 \%$ & -0.323037 \\
\hline LOG(IND_ES)) (Index of Ending Stocks) & $0.39 \%$ & 0.244521 \\
\hline LOG(IND_EXP) (Index of Exports & $1.50 \%$ & 0.572330 \\
\hline LOG(EXRATE) (Exchange Rate) & $0.04 \%$ & 0.554814 \\
\hline $\begin{array}{l}\text { LOG(INDEX_FUTVOL/INDEX_OPINT) }) \quad \text { (Index of } \\
\text { Futures) }\end{array}$ & $0.004 \%$ & 0.049314 \\
\hline $\begin{array}{l}\mathrm{LOG}\left(\mathrm{NC} \_\mathrm{LONG} /\left(\mathrm{NC} \_\mathrm{LONG}+\mathrm{C}_{-} \mathrm{LONG}\right)\right) \\
\text { (Long-term position }-2 \text { types of agents, private and } \\
\text { public) }\end{array}$ & $0.11 \%$ & 0.317493 \\
\hline
\end{tabular}

Table 3 - Percentage of increments of the dependent variable IND_PR when one explanatory variable (without the log transformation) is incremented by $1 \%$

\begin{tabular}{|l|c|}
\hline POP (Population) & $-4.39 \%$ \\
\hline BIOC_PROD ) (Biofuel production) & $0.23 \%$ \\
\hline IND_Y (Productivity Index) & $-0.96 \%$ \\
\hline IND_ES) (Index of Ending Stocks) & $0.27 \%$ \\
\hline IND_EXP (Index of Exports) & $1.21 \%$ \\
\hline EXRATE (Exchange Rate) & $0.50 \%$ \\
\hline INDEX_FUTVOL/INDEX_OPINT) (Futures) & $0.005 \%$ \\
\hline NC_LONG/(NC_LONG+C_LONG) (Long-term position & \\
2 types of agents, private and public) & $0.22 \%$ \\
\hline
\end{tabular}

In general, the inverse relationship between productivity and price is rather logical and consistent with historical trends, whereas the negative sign for the population coefficient implies that the growing world population does put a strain on the world agricultural systems indeed, but that this is not so much the case for the prices of the four cereals analysed here. The positive relationship existing between the long position of traders (on average correlated but the most significant variable of all, see Tables 2 and 1) and cereal price suggests that speculation does play a major role in explaining cereal price increases over the period. This finding is consistent across the two types of analyses (in levels and in percentage change terms, with and 
without a $\log$ transformation) as well as in the short-run (results not reported here).

The importance of arbitrage on international markets is corroborated by the result for exports which is also a highly significant explanatory variable. Although less significant, but highly correlated to the cereal prices, biofuel production does also play an important role in the upward trend of cereal prices, with a one percent increase in biofuel production resulting in nearly a 0.56 in a logarithmic scale, and 0.23 per cent without the $\log$ transformation in the price of the analysed cereals.

Finally, the positive and statistically significant relationship between prices and the dollar-euro exchange rate reflects the relative depreciation of the dollar vis-à-vis the euro over the time period, and it may throw a note of caution on the interpretation of price increases in nominal terms (the impact of this explanatory variable on cereal prices is 0.04 and 0.50 with and without a log transformation). Cereal prices are denominated in dollar terms, but food price increases are somewhat cushioned in countries with an appreciating exchange rate, such as those of the euro-area.

\section{Concluding remarks}

The present crisis shows some similarities with the world food crisis of the 1970 s when the green revolution was implemented. Bad whether conditions in 1972 caused world food production to drop, and this was followed by the 1973 oil shock. In that decade, world cereal prices were higher than ever before, and this lasted until the 1980s. Beyond these apparent similarities, what are the differences with the current situation? To answer this question, some relevant factors affecting world prices have to be recalled.

The short-term factors are generally recognised as conducive to price increases. These factors are: adverse weather conditions, reduction in food stocks, international trade policies (such as the imposition of export restrictions), modification of productive costs (energy, fertilisers), and marketing power as far as consumers are concerned. In the long-term, rising biofuel production, growing demand from emerging countries, and limited productivity growth can be listed. However, the issue surrounding the impact of these factors on commodity prices is rather complex.

Several studies have considered the impact of biofuel production on price cereals. A positive correlation has normally been underlined, but the measure of growing renewable energy on world cereal prices differs from author to author. Less explored has been the issue of speculation or arbitrage by international traders. 
With the help of a regression analysis, we identify a number of supply-side and demand-side independent variables that are responsible for cereal price trends. Our results show that speculation (defined by the long position of traders) has played a crucial role during the period under review (June 2001 - December 2009). According to our analysis, speculation it is the most relevant independent variable that affects cereal prices. Exports, in some ways connected to the former variable, occupy second place, in term of significance. However, their impact on cereal prices is less relevant than that of biofuel production, in terms of the shock represented by the price rise. Population growth (generally recognised as a positive determining driver of food/cereal prices) does not have impact in a positive way on cereal prices; it acts in the opposite direction due to the change in diets (from vegetable to animal proteins), implying that population increases would tend to affect primarily other agricultural markets.

Excessive volatility in food prices, as that observed in the last years of the period under study in this article, is a dramatic question. From a demand point of view, consumers in developing countries and vulnerable income groups in other countries have to be protected (Anriquez G. et a, 2010, Brown, 2006). Cereals are a staple food and, according to Engel's law, a large share of low-income group households' income is spent on food. With cereal prices increases, the likelihood of malnutrition increases. On the other hand, when prices decrease, supply tends to fall according to the direct relationship existing between quantity and price. Not surprisingly, high prices have tended to encourage an expansion in the global production of cereals in 2009. However, according to the FAO (2009), this increase in supply affects primarily developed and some emerging countries.

More than one policy on both international markets (trade related measures, stock policies, new rules on futures markets) and domestic markets (at production and consumption levels) have to be introduced so as to lessen food/cereal lower price volatility. Speculation, biofuel production and, to a lesser degree, productivity can be regulated. Even if it is still not clear whether speculation affected physical markets or whether it was the growth of the markets itself that nurtured speculation, it is clear from the analysis provided here that speculation can and has to be cushioned with more severe rules in the international markets. The limited fuel resources and their impact on climate changes require more biofuel production, but this could take place under the condition that the food security is more important than energy security (Peskett et al, 2007, Von Braun and Pachauri, 2006). Production can be boosted with a fairer access to inputs by farmers, mainly those leaving in rural and marginal areas. 
One way in which this analysis could be developed further is by disentangling the private operators from the public operators from the group of agents who take a long position.

\section{Bibliography}

Anriquez G, Daidone S, Mane E (2010) Rising food prices and undernourishment, a cross-country inquiry. ESA working paper No. 10-01. FAO.

Brown L (2006) Ethanol could leave the world hungry. Fortune.

FAO (2009) World food and agriculture in review.

IFRI (2008) Biofuels and grain prices: Impacts and policy responses.

Kutas, G, Lindberg, C and Steenblik, R (2007) Biofuels: At what cost? Government Support for Ethanol and Biodiesel in the European Union. A report for the International Institute for Sustainable Development, Geneva, Switzerland.

Mitchell D (2008) A note on rising food prices. Policy research working paper No. 4682. World Bank

Muller A (2008) Sustainable agriculture and the production of biomass for energy use. Climatic change 94: 319-331. doi: 10.1007/s10584-008-9501-2.

Pace N, Seal A, Costello A (2008) Food commodity derivatives: a new cause of malnutrition? The Lancet 371:1648-1650. doi:10.1016/S01406736(08)60707-2.

Peskett L, Slater R, Stevens C, Dufey A (2007) Biofuels, agriculture and poverty reduction. Natural resource perspectives 107, ODI.

Robles M, Torero M, Von Braun J(2009) When speculation matters. IFPRI Issue Brief 57.

Timmer PC (2009) Did speculation affect world rice prices? ESA working paper No. 09-07. FAO, Rome. 
Von Braun J, Pachauri RK (2006) The promises and challenges of biofuels of the poor in developing countries. IFPRI 2005-2006 annual report.

Wahl P (2009) Food speculation, the main factor of the price bubble in 2008. WEED. 